\title{
Myth as metaphor
}

Author:
Gert Malan'
Affiliation:
'Department New Testament
Studies, Faculty of Theology,
University of Pretoria,
South Africa
Research Project
Registration
Project Leader: E. van Eck
Project Number: 2400030
Description:
Dr Gert Malan is participating
in the research project,
'Socio-Cultural Readings',
directed by Prof. Dr Ernest
van Eck, Department of New
Testament Studies, Faculty of
Theology, University of
Pretoria.
Code with your
smart phone or
mobile device
to read online.
Gert Malan,
Geading author:
gertmalan@telkomsa.net
Dates:
Received: 19 Nov. 2015
Accepted: 31 Dec. 2015
Published: 08 July 2016
How to cite this article:
Malan, G., 2016, 'Myth as
metaphor', HTS Teologiese
Studies/Theological Studies
72(4), a3260. http://dx.doi.
org/10.4102/hts.v72i4.3260
Copyright:
C 2016. The Authors.
Licensee: AOSIS. This work
is licensed under the
Creative Commons
Attribution License.

Modern Christianity has failed to update its myths and has even eliminated them, thus, excluding the metaphysical experience indispensable to religion (Jung). Myths should be interpreted, not eliminated. Answering the question about how to interpret myths without eliminating them or their intended effect is the object of this paper. The study investigates the possibility of interpreting myths as metaphors, thus, in a non-literal way. Various definitions of metaphor and myth, and theories for their interpretation are discussed, with focus on their relationship to symbolic universes. Finally, a non-mythical symbolic universe structured by root-metaphors is suggested as a framework for the existential interpretation of mythical concepts in the New Testament.

\section{The need for myth}

According to Carl Jung, modern Christianity has failed to update its myths and erred in updating itself by eliminating myth (Segal 1998:37) implying possible future self-elimination. Jung's criticism underlines the human need for myth. Myth refers to the narrative threads from which a culture's mythology (a mythical worldview as a frame of reference) is woven (Malan 2015:1-2) and, thus, myth cannot be separated from it. Mythical narratives evolve in a natural way as part of folklore (Kleinliteratur) and are not the literary product of individuals [Hochliteratur] (Van Aarde 2003:245). Examples of Kleinliteratur ${ }^{1}$ are proverbial sayings, anecdotes, heroic legends, fairy tales, and folksong (Bultmann [1921] 1963:6-7), transmitted from one generation of a culture to the next, developing new motifs and variants in a way reminiscent of stalactite formation (Kundera [1967] 1992:140-141). As such, they are part of a culture's Weltanschauung and Selbstverständnis (Heidegger [1927] 1996:49-58) ${ }^{2}$ or 'symbolic universe' (the term sociology of knowledge prefers) and without which no society can survive as it legitimises and explains societal norms, institutions and functions (Berger \& Luckmann ([1967] 1975:113-120). Society's, and in this case, specifically the Church's need for myth, necessitates the interpretation of ancient New Testament myths in such a way that it weaves a new or evolved, existentially meaningful symbolic universe. This is the challenge as I understand it, which Jung has put to modern Christianity.

This article proposes such an answer to Jung's challenge by interpreting myth as metaphor. The essence of metaphor and myth will be investigated to determine the viability of interpreting myth as metaphor. The paper concludes with an example of metaphoric interpretation of myths, by identifying root metaphors structuring a symbolic universe as a framework for the interpretation of mythical narratives.

\section{The essence of metaphor}

'Metaphor (from the Greek metapherein, meaning 'transference') is a figure of speech in which a word or phrase is used to describe something it does not literally denote' (McGlone 2007:109). A word or phrase denoting one kind of object is used in place of another to suggest a likeness or analogy between them. The comparison is implied, not indicated as with similes. It is a more immediate, concrete and descriptive method of comparison (Van Staden 2005:105-106). The study of metaphor reaches back to antiquity. Aristotle's (384-322 BCE) definition of metaphor, mentioning four kinds, can be regarded as an acceptable point of departure:

Metaphor consists in giving the thing a name that belongs to something else; the transference being from genus to species, or from species to genus, or from species to species, or on grounds of analogy ... That from analogy is possible whenever there are four terms so related that the second is to the first, as the fourth is to the third; for one may then put the fourth in place of the second, and the second in place of

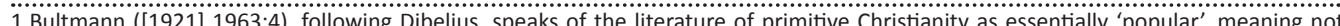
aesthetically evolved regarding literary form, thus, necessitating understanding of their 'life situation' for their proper interpretation (form-critical approach).

2.According to Heidegger, Dasein cannot be defined without referring to the world, and the world cannot be defined without referring to Dasein. Worldview is more than a mere frame of reference. It constitutes our relatedness to the world and others [Mitdasein and Einfühlung] (Heidegger [1927] 1996:107-137), implying that there is no existence other than being in the world and sharing it with others (Mitwelt) (Heidegger [1927] 1996:110-122). 
the fourth (Ars Poetica 1457b7-18, as quoted by Ashworth 2007:312-313).

From this definition in Ars Poetica, Ricoeur (1977:13-23) notes four dynamic characteristics of metaphors:

- Something happens to the noun in the sentence or phrase.

- Metaphor is defined in terms of movement (it is a transference of terms).

- It is the transference of a name that is 'alien' (dissimilar; belonging to something else).

- Metaphor preserves the unity of meaning through transference.

Another statement of Aristotle's regarding metaphor, underlines the importance of dissimilarity:

[The] greatest thing by far is to be a master of metaphor. It is the one thing that cannot be learnt from others; and it is also a sign of genius, because a good metaphor implies an intuitive perception of the similarity in dissimilars. (Ars Poetica. 1459a, as quoted by Hausman 2006:214)

Metaphor suggests a creative act by a creator with intuition to perceive a similarity regarding two dissimilars, which needs to be intuitively appreciated, leading to the discovery of the similarity within the dissimilarity (Hausman 2006:214; see also Van Staden 2005:106). The meaning conferred by a metaphor is the result of a confrontation of the dissimilar elements constituting the metaphorical process and unlocking the meaning, which will be based on the interpreters' personal associations (Van Luxemburg, Bal \& Westeijn 1983:239).

In Ars Rhetorica, Aristotle spoke about the strategy of persuasion and discussed the virtues of metaphor in this regard as clarity, warmth, facility, appropriateness and, above all, elegance, which includes liveliness of expression and the power to surprise. He indicated that metaphor has an instructive value, namely caused by the pleasure of the moment of understanding that follows surprise. For this function, metaphor instructs by suddenly combining elements that have not been combined before (Ricoeur 1977:36-37), nevertheless Aristotle repeatedly warned against the use of metaphors for definitions (Ashworth 2007:315).

After Aristotle, his ideas about metaphor were extensively discussed, even by medieval logicians ${ }^{3}$. Terms regarding the dynamics of metaphor, such as translatio and transumptio were of importance, although they cannot be summarily equated to metaphor (Ashworth 2007:316-317, 320-321). ${ }^{4}$

3.Several translations and commentaries were written of which a few are extant, such as Hermannus Alemannus' 1256 translation of Ars Poetica leading to Bartholomew of Brugges's commentary, William of Moerbeke's translation of Ars Rhetorica(1269) and Giles of Rome's commentary (1271-1274) (Ashworth 2007:316-317).

4.Translatio is part of the originally Stoic theory of tropes and figures of speech. A 'trope' is the change [mutatio] of a word or phrase from its proper signification to another signification with some added force [cum uirtute]. Translatio can refer to another signification with some added force [cum uirtute]. Translatio can refer to the Greek word metaphora (Quintilian, first century CE rhetorician from Spain) or trope as an expression translated [translata] from its proper signification to an improper similitude [non propriam similitudinem] (Donatus, fourth century grammarian and rhetorician). Transumptio, according to Quintillian, was metalepsis, which occurs with double transference, namely when a word in question replaces another word, which in turn replaces another word and so on (Ashworth 2007 316-317; 320-321).
In the thirteenth century, Giles of Rome wrote a popular commentary on Aristotle's Ars Rhetorica. According to him, Aristotle's four kinds of metaphor are as follows:

- asteyum (or asteycum) [a lively, witty metaphor with strong analogy, used for teaching]

- proverbium [proverbial wisdom sayings]

- transumptio [the simplest form of metaphor, e.g. 'Achilles is a lion']

- assimilatio [a simile to which is added a certain analogy] (Ashworth 2007:314-315).

\section{Contemporary metaphor theories}

Metaphor was eventually relegated to rhetoric and literary style, with the unfortunate effect that generations of linguists ignored the topic until the turn of the twentieth century, when Breal, a French linguist's Essai de Semantique (1899) sparked new interest, especially amongst American linguists and philosophers. Breal argued that metaphor was more than ornamental. It was a ubiquitous feature of language and a principal device of linguistic change (Hausman 2006). Hausman explains that he was followed by Richards (1936) who introduced special terminology: the 'vehicle' (the term used metaphorically), the term to which it is applied is the 'tenor' or 'topic' (the main idea that is to be articulated in the metaphor). His interaction theory refers to the way the components of the metaphor interact with one another to generate something different from the meaning of either or all of the components (Hausman 2006:216). The meaning of the metaphor is called the 'ground'. Later, Max Black (1967) also rejected Aristotle's views as too simplistic. Black argued that metaphor is a way of communicating that operated on a deeper level of conceptual structure rather than on mere word meaning. He expanded Richards' interaction theory by carefully describing the subtleties of interactions which Richards described only briefly (Hausman 2006:216), according to which metaphors are understood by observing the 'tenor' concept in terms of the 'vehicle concept' to produce a 'ground' that combines and transcends their literal denotations ('figurative transcendence'). Black was rightly criticised for his vague account of figurative transcendence but the interaction theory was nonetheless followed by many others as preferable alternatives to Aristotle's idea of comparison (McGlone 2007:110). According to Black, metaphors may create similarities rather than simply disclose qualities not before noticed (comparative view). He called the similarities 'unprecedented perspectives' (Hausman 2006:216). If one regards Aristotle's approach as the comparison view of metaphor, some twentieth century followers such as Marcus Hester (1967) and Virgil Aldrich (1968) developed a 'seeing as' theory. Two things are compared, inviting the interpreter to 'see one object as if it were another'. The various versions of the comparison view assume that metaphors can be paraphrased. Criticism followed, especially regarding the aspect of cognitive dissonance, which contemporary proponents of the comparison view think could be resolved through paraphrasing, in contrast to the interactionist theorists who do not (Hausman 2006:215-216). 
The contemporary theory of metaphor or CTM, evolved from the previously called 'conceptual metaphor theory' or CMT of Lakoff and Johnson (Ibanez \& Hernandez 2011:161), which can be viewed as a refinement of Black's initial theory. It has dominated the field since the 1980's, thus, replacing earlier theories viewing metaphor as decorative and restricted to literary language. CTM emphasises the conceptual aspect of metaphor and downplays its language aspect. The traditional view of metaphor did not regard metaphor as reflecting pre-existing aspects of how people ordinarily conceptualise ideas and events in terms of pervasive metaphorical schemes. During the past three decades cognitive linguistics investigated the idea that people speak metaphorically because they think, feel and act metaphorically. Formal structures of language are, therefore, not studied as if they were autonomous, but as reflections of general conceptual organisation, categorisation principles and processing mechanisms (Tendahl \& Gibbs 2008:1825; see also Ibanez \& Hernandez 2011:162). Cognitive linguistcs has found that there is a huge system of metaphor that structures our everyday conceptual system. It includes abstract concepts and it lies behind much of our everyday language, rendering the traditional literal-figurative distinction obsolete. Consider a love relationship described by the following ordinary, everyday expressions:

Our relationship has hit a dead end. Look how far we have come. It's been a long, bumpy road. We can't turn back now. We're at a crossroads. We may have to go our separate ways. The relationship is not going anywhere. Our relationship is of the track.

They all conceptualise love as a journey, with the suggestion that the relationship has stalled, that the lovers cannot continue in this way (Lakoff 1986:215-216). They must turn back or abandon the relationship. These expressions are not poetic but ordinary. Cognitive linguists investigate the general principles behind linguistic expressions such as this. They conclude that it is part of our conceptual system underlying language (Lakoff 1986:218; Lakoff 1993:204-205).

The following conclusions regarding metaphor and cognition are made:

- 'Metaphor is the main mechanism through which we comprehend abstract concepts and perform abstract reasoning.'

- 'Most subject matter can only be comprehended via metaphor.'

- 'Metaphor is fundamentally conceptual rather than linguistic in nature.'

- 'Metaphorical language is a surface manifestation of conceptual metaphor.'

- 'Much of our conceptual system is metaphorical but not all of it. Metaphorical understanding is grounded in nonmetaphorical understanding.'

- 'Metaphor allows us to understand abstract or inherently unstructured subject matter in terms of a more concrete or at least more' structued subject matter. (Lakoff 1993:228-229)
Cognitive scientists regard metaphor not just a matter of language, but of thought and reason. What constitutes the metaphor 'love as a journey' is the ontological mapping across conceptual domains, from the source domain of journeys to the target domain of love. The mapping is primary and the language is secondary. The mapping is primary as it sanctions the use of source domain language and inference patterns for target domain concepts. The mapping is a fixed, conventional part of our conceptual system (Lakoff 1993:206-207; 228-229). Regarding our example, it is one of our conventional ways of conceptualising love relationships. The relationship expressions used above are not regarded as a number of different metaphors but one metaphor in which love is conceptualised as a journey, realised in many different linguistic expressions. 'Conceptional metaphor', which functions like a root metaphor (see discussion below), refers to conceptual mapping. The various linguistic expressions called 'metaphorical expressions', are similar to metaphors nuancing root metaphors. 'A conceptual system contains thousands of conventional metaphorical mappings, which form a highly structured subsystem of the conceptual system. The system of conventional conceptual metaphor is mostly unconscious, automatic' and used with little effort, like our language system and the rest of our conceptional system (Lakoff 1993:206-207; 228-229). The neural theory of metaphor was devised to explain how the human brain functions with regard to metaphors. The brain is viewed as structured by thousands of embodied metaphor mapping circuits that create an extraordinary richness within the human conceptual system. They function largely unconsciously. These mapping circuits asymmetrically link distinct brain regions, allowing reasoning patterns from one brain region to the other. Each circuit characterises a different form of metaphorical thought. Though metaphorical in content, the circuits reflect a reality, that is real correspondences in real-world physical and social experiences since childhood (Lakoff 2014:5). Lakoff's theory suggests that humans are neurologically empowered for metaphorical reasoning. This description of a conceptual system, constituted by metaphorical concepts and expressed in the form of metaphorical expressions, can be regarded as synonymous to symbolic universes supported by root metaphors, expressed with metaphorical expressions, or mythical Weltanschauungs supported by mythical narratives. Thus, cognitive science demonstrates the power of metaphor to construct (new) worlds.

\section{The power of metaphor to construct worlds}

American philosopher Charles Peirce (1839-1914) considered concept formation from a scholastic Aristotelian viewpoint and viewed concepts not as constrained by language, as they can exist prior to and independent of language as a potential (Sørenson \& Thellefsen 2006:199). This potential is independent of the human mind. However, the moment when potential partakes in a reasoning process, it becomes a sign of the symbolic kind, which develops its own potential during the concept formation process. Yet still it refers to its dynamical object. The symbol is a manifestation (an immediate object) of its dynamical object, and as such is an 
interpretation. Manifestations are a special kind of sign, referred to as replicae, containing qualities of the object and, thus, refer to the object without ever exhausting the qualities of symbol (Sørenson \& Thellefsen 2006:199).

To Peirce, man himself was a sign in a universe filled with signs. With this viewpoint, Peirce removed the barrier between man and nature (the universe). In its place he proposed a parallelism: 'the nature of reasoning - the reasoning of nature', to show the process of semeiosis as the same process by which habits are formed and rationality constantly grows. If we are not able to reason without signs, it follows that cognitive problems are semeiotic problems. Peirce describes a sign as 'something by knowing which we know something more' (Peirce in Sørenson \& Thellefsen 2006:200). It is important to note that Peirce regards cognition as a triadic relation between three terms: 'the representamen, object and interpretant', which together make up the sign (Sørenson \& Thellefsen 2006:200). This statement is important because it shows that a sign is inherently a metaphor as it represents an object, and the sign again must be interpreted. Thus, signs and metaphors function in much the same way, except that metaphors are twofold signs. A sign, signifying an object, is called the name of another sign signifying another object, thus, transferring meaning and combining dissimilars in one unity.

In Peirceian terms, metaphor is viewed as founded in the logic of otherness and excess and involves a movement of displacement that leads sense outside the sphere of the same, the commonplace, plain meaning. Metaphor activates interpretive trajectories in signifying processes and relates regions in the sign network that may be far separated from each other. This results in the elimination of systemic or typological limitations on meaning. Metaphor rather contributes to the development of meaning through boundless interpretive trajectories. Therefore, metaphor can be described as the very place in human language systems where sense is generated. 'Metaphorisation' is a movement of perpetual displacement distant from the plain meaning, leading to the conclusion that meaning cannot be grasped once and for all, but is an endless opening up to the otherness of sense (Petrilli 2006:76-77).

Peirce describes metaphor as belonging to the iconic order of signs, which is the only way of communicating ideas. An icon represents the qualities of its object and stands in a relation of similarity to its object (Sørenson \& Thellefsen 2006:201). As an iconic sign, metaphor presents a relation of similarity between 'interpreted' sign and 'interpretant' sign, and carries out an important role in the transmission of knowledge and innovation (Petrilli 2006:77). The 'interpretant' is an idea which carries meaning and is produced within the relationship between a sign and an object and can be described as 'mental effect' or 'thoughts' or 'a sign further developed'. Therefore, meaning can be described as almost synonymous with the translation of a sign from one sign network to another, thus, there is no 'final interpretant' and a 'sign as object' cannot be the same 'interpretant' once and for all times (Van Aarde 2003:259). This conclusion is confirmed by the potential of metaphor to develop an infinite sequence of signs that interpret and amplify the preceding sign, thus, intensifying a metaphor's power to create new worlds.

Metaphor enhances the process of understanding, interpretation and invention as it identifies or creates relations that were not previously observed or are completely new. In this sense, metaphor is more than a rhetorical device or an instrument of research, but is structural to the process of meaning production and the acquisition of knowledge. Viewed in this way, the concept of truth is connoted in terms of multiplicity and complementarity amongst different viewpoints (Petrilli 2006:78-79). The implication is that there is no final, objective truth and no final interpretation of any truth, suggesting that there is no ultimate world (utopia). Worlds (social universes), as human constructions, are plural as are the truths that legitimate them (symbolic universes). If metaphor has the power to construct social worlds it also has the capacity to destroy these worlds and replace them with new or variant worlds or bring about an evolution of these worlds. In this sense there is a similarity between metaphors and symbolic universes, without which no social world can survive or function. Metaphor legitimates or destroys worlds just as symbolic universes legitimate social institutions, roles and values and can endanger and destroy opposing social worlds by challenging their symbolic universes.

\section{Narrative myth}

As with metaphor, the study and defining of myth reaches back to antiquity, with Homer's distinction between historic tale [logos] and myth as legend or story (Van Staden 2005:107). Pindar called myth fiction, the Sophists following Homer, discerned between mythos and logos, and Plato used mythos to denote early Greek legends of the gods (Groenewald 2006:911). In comparison, Aristotle viewed myth as the plot of a narrative (Ricoeur 1977:40-41; see also Ricoeur 1992:143). From these sketchy definitions a multitude of definitions developed, accentuating the interpreter's focus on certain contents or functions myths may have. Hermann Gunkel (1922:xi) described myths as stories of the gods, in contrast to sagas as 'historical' narratives about humans ('historical' refers to events that actually took place somewhere). Mircea Eliade described myths as 'sacred history' (Segal 1999:2) whereas Stewart (1971:76) viewed ancient myths as an expression of a sense of the past.

Bultmann ([1952] 1965:183) accepted the Religionsgeschichtliche definition of myths ${ }^{5}$ and viewed myths as expressions of human existence as grounded in a transcendental power beyond human calculation and disposal. Bultmann called the New Testament mythical narratives analogische Rede (Bultmann [1952] 1965:196) as they spoke of God's actions in terms of human actions, using the term 'analogy' according

5.Previously, I investigated Bultmann's definition of myth and his demythologisation program (Malan 1998; 2000:1107-1118; 2015:1-8; 2016) and will only focus on his views on myth relevant to analogy and, thus, to metaphor. 
to Erich Frank's definition of '... a similarity of relations in general, as a relation of relations' (Frank 1945:162). Frank's view of analogy is reminiscent of Aritotle's definition of metaphor. This conclusion is supported by Frank's statement:

Man, in his discourse with God can only use his own words. If he speaks of God as Our Lord and Father, of his will, his providence, all such concepts are taken from human life; they are not to be understood literally, but rather as metaphors. (Frank 1945:97)

But this does not mean that metaphorical language about God replaces God's actions with analogies. 'Thus, God's love and care, are not images or symbols; these conceptions mean real experiences of God as acting here and now' (Bultmann 1958:69).

Mythical narratives were plausible in their historical context because they fitted the mythological frame of reference, acting as primitive science, explaining the inexplicable phenomena in this world by referring to the otherworldly (Bultmann [1941] 1967:23). Myths were made plausible because of mythical thinking, as opposed to modern scientific thinking, namely that the world and human lives are open to the influences of otherworldly forces and beings (Bultmann [1952] 1965:180). This conclusion is reminiscent of the contemporary metaphor theory's idea, that metaphors originate from metaphorical thinking, for which humans are neurologically wired. Furthermore, there are resemblances between myth and mythology and contemporary theory of the terminology of metaphor; of conceptual metaphors constituting a conceptual system, within which metaphorical expressions find their meaningful place.

A very complex definition of myth is provided by Doty, which compares in complexity to the contemporary theory of metaphor. Doty (1980) includes no less than seventeen aspects in his definition:

A mythological corpus consists of (1) a usually complex network of myths, which are (2) culturally important (3) imaginal (4) stories, conveying by means of (5) metaphoric and symbolic diction, (6) graphic imagery, and (7) emotional conviction and participation, (8) the primal, foundational accounts (9) of the real, experienced world, and (10) humankind's roles and relative statusses within it. Mythologies may (11) convey the political and moral values of a culture, and (12) provide systems of interpreting (13) individual experience within universal perspective, which may include (14) the intervention of suprahuman entities, as well as (15) aspects of the natural and cultural orders. Myths may be enacted or reflected in (16) rituals, ceremonies and dramas, and (17) they may provide materials for secondary elaborations, the constituent mythemes having become merely images or reference points for a subsequent story, such as a folktale, historical legend, novella or prophesy. (pp. 533-534)

Other definitions of myth echo what theorists say about metaphors regarding analogy, dissimilars and transference of meaning. Burton Mack understands myth to be an imagined world 'which prompt[s] reflection upon aspects of the actual social situation ...' (Mack, as quoted by Reed 2014:203). This imagined world is not just a collection of stories, but it is a way of engaging the world. From the viewpoint of anthropology, the anthropomorfic quality is viewed as 'an inherent feature of myth, determining its whole structure and logic of functioning. Thus, being a "human" view of the world, myth creates a syncretic picture of this world' (Tychkin 2015:461), in which humans are an integral part. The meaning in myth is created with the merging of internal and external, intelect and sense, where reality is not set by any of them but is formed at its unity with a human at its heart (Tychkin 2015:461). Myths, like science, attempt to make the world intelligible and, as such, constitute a unique form of discourse through which we gain an understanding of our place in the world and how to live in it (Stawinski 2005:75). Carl Jung views the cosmic myths not as describing the beginning of the world, but rather the beginning of consciousness as a second creation. According to Jung the myths describe psychical processes and developments, which show themselves to be inaccessible to any deliberate change as long as they remain in the unconscious state, where they have a forceful influence upon consciousness. This influence cannot be suspended nor corrected by conditions of the environment and, therefore, they have been considered from earliest time as daemonium. No rationality can change this empirical fact. When Jung calls the archtypes instincts, demons or gods, it does not alter their effective existence. Therefore, Jung thought his insights made possible a new understanding of mythology and its importance as expression of inner psychical processes (Jung [1959] 1971:43-47). In this sense, as with Bultmann's demythologising, myth is left in place, but an interpretation is offered. Jung is followed by Campbell (1972:13), who views myths as telling in picturesque language of our psychic powers and how to recognise and integrate them in our lives. Segal (1999:72-73) underlines an important nuance of Jung's understanding of myth, namely that myths convey meaning to their adherents: they reveal their unconscious contents to those whose myths they are. Honko (1984:51) describes myth as ontological, as it is integrated into a coherent worldview and describes important aspects of life and the world.

Can myths be interpreted as metaphors? The various and diverse definitions seem to comfirm that narrative myths share the traits of metaphors for the following reasons:

- They are types of analogy.

- Dissimilars are combined in a relationship (humans and gods).

- They transfer meaning from one realm to another.

- They are explanatory.

- They are context bound.

- They fit into a comprehensive structure of meaning (worldview) of a culture.

- They become a meaningful way of thinking and being to their adherents (create and shape worlds).

- They need to be interpreted.

We can, therefore, legitimately interpret myths in the way that metaphors are interpreted, opening new possibilities for the restructuring of symbolic universes on the basis of root metaphors (or conceptional metaphors) nuanced by narrative myths. This conclusion is supported by Doty (1980:539-540) 
who speaks of myth as metaphor and views the mythographer's role as disclosing and uncovering the metaphorical powers of mythological expression, and Groenewald (2006:911) who treats myth as 'poetic metaphor'. Armstrong (1999:11) concurs that 'myths were not intended to be taken literally, but were metaphorical attempts to describe a reality that was too complex and elusive to express in any other way'.

\section{Root metaphors as the structure of symbolic universes}

As mentioned in the introduction, I view narrative myths as threads of the cloth of symbolic universes. The structure of the symbolic universe is provided by root metaphors as the ruling images of societies, which are coded in mythological language. These myths, functioning as root metaphors '... structure the overarching conceptualities of a society ...' (Doty 1980:539), which he describes as worldviews, but which can also be called 'mythology', 'symbolic unverse' and 'worldview' [Weltanschauung] (Malan 2016b). In this sense, myths can be described as ontological, as they are incorporated into a coherent view of the world (Honko 1984:51). Cassirer explained myth as '... a type of perception, actions, customs, images, and pictorial representation. Myth is a type of living, feeling and knowing' (Cassirer, as quoted by Schultz 2000:32).

Ricoeur likened the interpretation of a text or any cultural phenomenon to the interpretation of a metaphor. Interpreters should construct something original from the new and unknown world that the metaphor or text has unlocked. This should be a new vision of reality which was not yet known to them and should be a broadening of the reader's comprehension (Van Luxemburg, et al. 1983:74).

Take for example the New Testament root metaphors denoting the relationship between God and the faithful: God is described as a father to his children, a master to his slaves, ruler over his subjects (the kingdom of God), and as judge providing a lawyer to defend his unworthy clients in court to facilitate his pronouncement of righteousness. Jesus as the Son of God is often depicted as the broker of the patron-client relationship between God and the faithful. Thus, the four relationships mentioned are root metaphors for the symbolic universe of God's patronage towards the faithful clients (see Figure 1). Patronage refers to a life-long reciprocal social relationship between unequal partners. The lower status person (client) has his needs met by a higher-status patron. The client, having been granted favour, reciprocates by serving the patron. Once committed, the patron accepts the responsibility for further assistance of the client. The relationship is brokered by a third party, for example a son of the patron (Malina \& Rohrbaugh 2003:388-390). Patrons were viewed as protectors of their clients as they cared for them monetarily, provided for their safety and for defence in court (roman-empire.net n.d.) .

Loyalty [fides] was the essence of the patron-client relationship, which held together families and provided order and stability in societies. It also acted as a welfare network to support the poor and deprived, as the state did not have such mechanisms. The clients acted as a clan for the patron, but were also bound to each other by loyalty. They had to care for one another, and protect and help each other, especially if one was in dire need (roman-empire.net n.d.). Love, in the patron-client system, meant honourable loyalty (attachment) to a person or group. Hate meant dishonourable indifference and disattachment. To love God as patron (symbolic universe) means loyalty, total devotion and attachment to God, as well as his other clients (social universe) (Malina \& Rohrbaugh 2003:380) (see Figure 2).

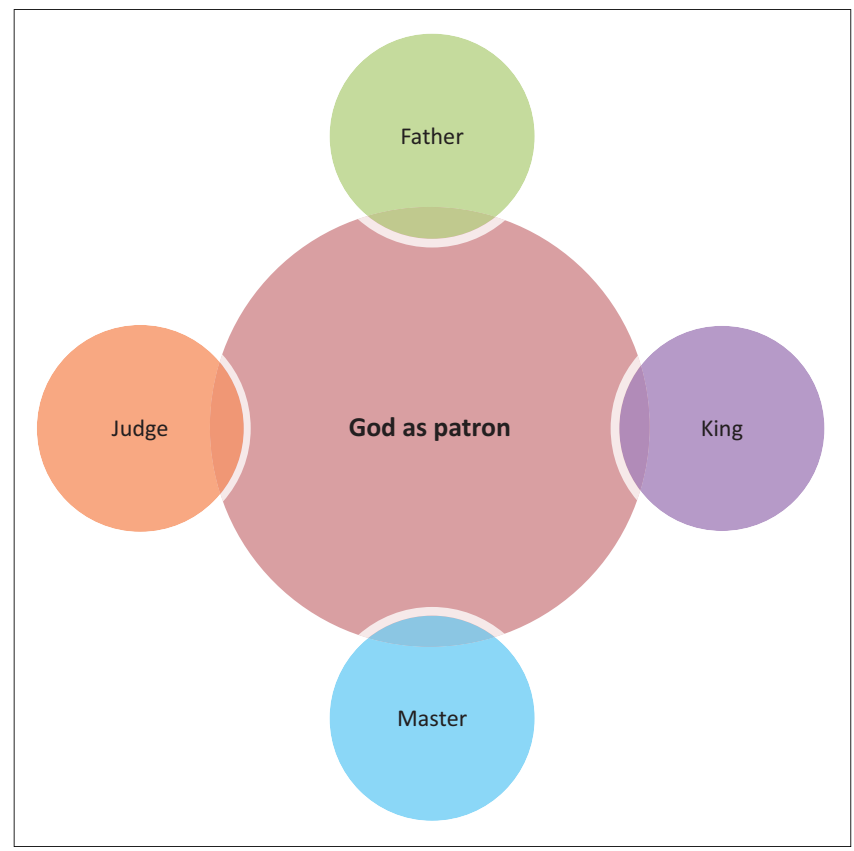

Source: Malan, G

FIGURE 1: Symbolic universe of God's patronage and its root metaphors.

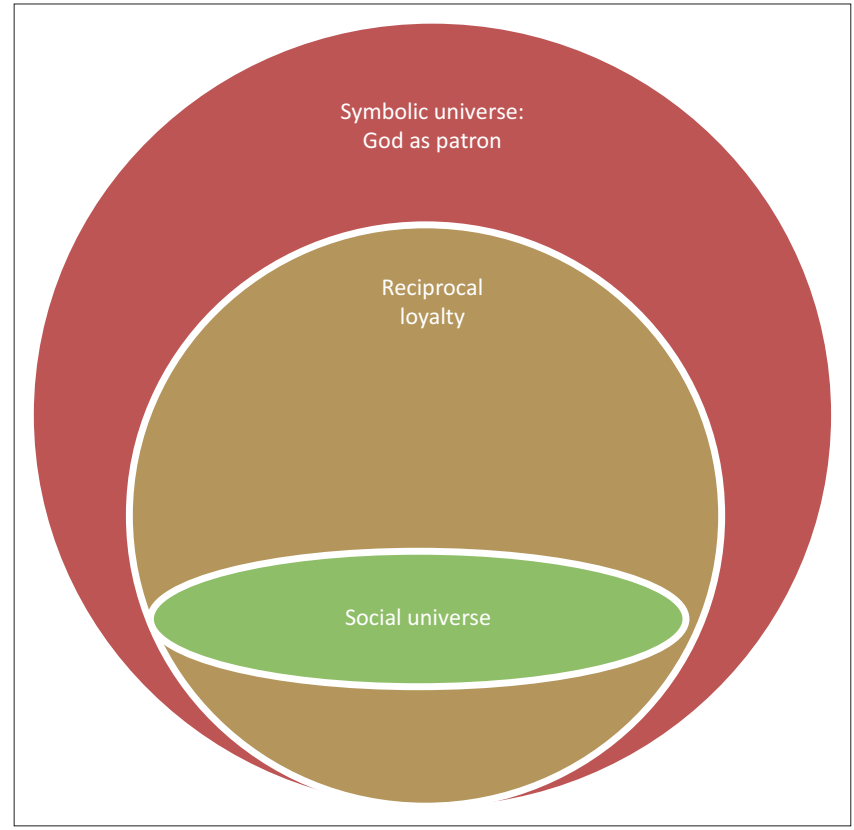

Source: Malan, G

FIGURE 2: Symbolic universe of God as patron that spans his clients' social universe. 


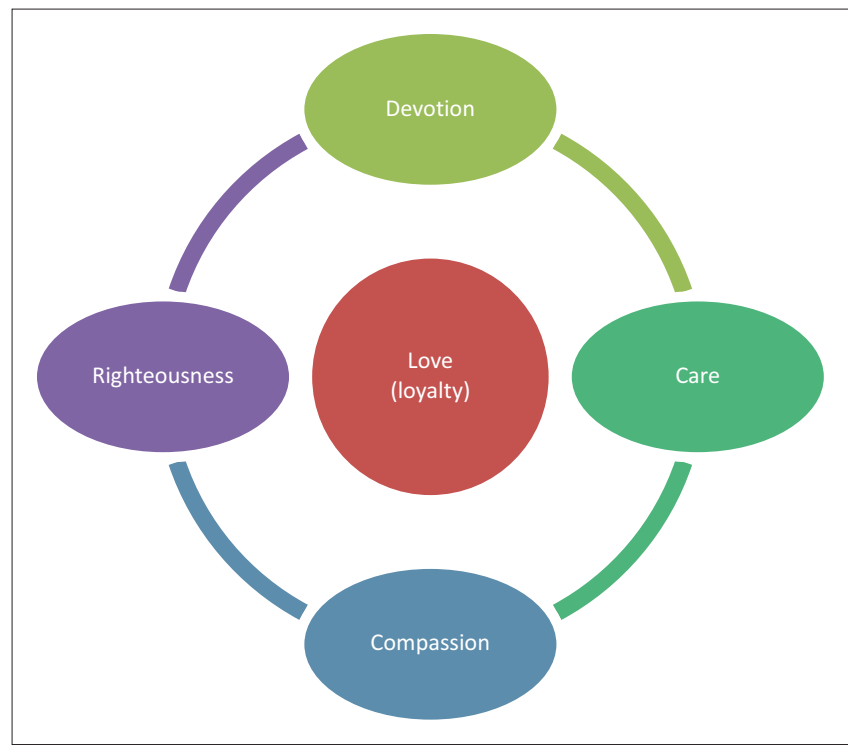

Source: Malan, G

FIGURE 3: The loyalty bond between patron and clients, and between clients.

Aspects of the reciprocal relationship between God and client, and between clients (motivated by God's love) can be illustrated as seen in Figure 3.

\section{Arriving at a non-mythical symbolic universe}

Jung's challenge for updating the mythological aspect was accepted by identifying root metaphors forming the structure of the symbolic universe. Mythological narratives speaking of sin, salvation, the cross and resurrection can be interpreted in terms of God patronage, which Jesus brokered. Within such a symbolic universe faith cannot be mere belief, but is a way of life loyal to God and the faithful, to which the faithful have been freed. Apocalyptic concepts like the parousia and last judgement will be replaced by existential choices made in the moment of decision, to be judged in terms of loyalty. Thus, a non-mythological symbolic universe was identified that legitimates and structures the devotion of the church and the lives of the faithful. Western people living in the twenty first century are not familiar with the system of patronage. There are two choices:

- Patronage can be explained as a metaphor for the relationship between God and his faithful, and amongst themselves.

- Patronage can be deconstructed (see Malan 2014:7-8).

Both result in a non-mythical, existential understanding of the relationship between God and the faithful.

\section{Acknowledgements Competing interests}

The author declares that he has no financial or personal relationships which may have inappropriately influenced him in writing this article.

\section{References}

Armstrong, K., 1999, A history of God, Vintage, London.

Ashworth, E.J., 2007, 'Metaphor and the Logicians from Aristotle to Cajetan', Vivarium, vol. 45, pp. 311-327.

Berger, P.L. \& Luckmann, T., [1967] 1975, The social contruction of reality. A treatise in the sociology of knowledge, Penguin, Harmondsworth.

Bultmann, R.K., [1921] 1963, The history of the synoptic tradition, Blackwell, Oxford.

Bultmann, R.K., [1941] 1967, 'Neues Testament und Mythologie: Das Problem der Entmythologisierung der neutestamentlichen Verkündigung', in H.W. Bartsch (ed.), Kerygma und Mythos I: Ein theologisches Gespräch, pp. 15-48, Herbert Reich Evangelischer Verlag, Hamburg-Bergstedt.

Bultmann, R.K., [1952] 1965, Zum Problem der Entmythologisierung, in H.W. Bartsch (ed.), Keryma und Mythos II: Diskussionen und Stimmen zum Problem der Entmythologisierung, pp. 179-195, Herbert Reich Evangelischer Verlag, HamburgBergstedt.

Bultmann, R.K., 1958, Jesus Christ and mythology, Charles Scribner's Press, New York. Campbell, J., 1972, Myths to live by, Bantam, New York.

Doty, W.G., 1980, 'Mythofiles' Dyscrasia: A Comprehensive Definition of Myth', Journal of the American Academy of Religion XLVIII(4), pp. 531-561.

Frank, E., 1945, Philosophical understanding and religious truth, Oxford University Press, London.

Groenewald, A., 2006, 'Mythology, Poetry and Theology', HTS Theological Studies 62(3), pp. 909-924.

Gunkel, H., 1922, Genesis, übersetzt und erklärt, Vandenhoeck \& Ruprecht, Goettingen.

Hausman, C., 2006, 'A review of metaphorical theory and metaphorical reference revisited', Semiotica 161 vol. 1, pp. 213-230.

Heidegger, M., [1927] 1996, Being and Time, State University of New York Press, New York.

Honko, L., 1984, 'The problem of defining myth', in A. Dundes (ed.), Sacred narrative: Readings in the theory of myth, pp. 41-52, Noonday, New York.

Ibanez, F.J. \& Hernandez, L.P., 2011, 'The Contemporary Theory of Metaphor: Myths, Development and Challenges', Metaphor and Symbol vol. 26, pp. 161-185.

Jung, C.G., [1959] 1971, 'Religionless Christianity. A Letter by Carl G. Jung', Journal of the American Academy of Religion, vol. 39, pp. 43-47.

Kundera, M., [1967] 1992, The joke, Faber \& Faber, London.

Lakoff, G., 1986, 'A Figure of Thought', Metaphor and Symbolic Activity 1(3), pp. 215-225.

Lakoff, G., 1993, 'The contemporary Theory of Metaphor', in A. Ortony (ed.), Metaphor and Thought, pp. 202-251, 2nd edn., Cambridge University Press, Cambridge.

Lakoff, G., 2014, 'Mapping the Brain's Metaphor Circuitry: Metaphorical Thought in Everyday Reason', Frontiers in Human Neuroscience, vol. 8, pp. 1-14.

Mack, B.L., 2014, 'A Secular Bible?', Method \& Theory in the Study of Religion, vol. 26, pp. 183-201.

Malan, G.J., 1998, " $\mathrm{n}$ Herwaardering van Rudolf Bultmann se Ontmitologiseringsprogram in die lig van die Kennissosiologie. Die Dag van die Here in 2 Petrus as voorbeeld', DD Dissertation, Faculty of Theology, Deptment New Testament Studies, Pretoria University.

Malan, G.J., 2000, 'Bultmann se Ontmitologiseringsprogram herwaardeer', HTS Theological Studies 56(4), pp. 1107-1118.

Malan, G.J., 2014, 'The kingdom of God: Utopian or existential?', HTS Teologiese Studies/Theological Studies 70(3), Art. \#2109, 9 pages. http://dx.doi.org/10.4102/ hts.v70i3.2109

Malan, G.J., 2015, 'Die Nuwe Testament en Mitologie: Die Probleem van die Ontmitologisering van die Nuwe-Testamentiese Verkondiging: Bultmann se 1941 opstel weer bekyk', HTS Theolocal Studies 71(3), p. 1-8, Art. \#2757, 8 pages.

Malan, G.J., 2016a, 'Combining Ricoeur and Bultmann on Myth and Demythologising', HTS Theological Studies (in press).

Malan, G.J., 2016b, 'Mythology, Weltanschauung, Symbolic Universes and States of Consciousness', HTS Theological Studies (in press).

Malina, B.J. \& Rohrbaugh, R.L., 2003, Social-Scientific Commentary on the Synoptic Gospels, 2nd edn., Fortress, Minneapolis.

McGlone, M.S., 2007, 'What is the Explanatory Value of a Conceptual Metaphor?', Language \& Communication, vol. 27, pp. 109-126.

Petrilli, S., 2006, 'Meaning, metaphor, and interpretation: Modeling new worlds', Semiotica 161(1), pp. 75-117.

Reed, R., 2014, 'Secularism and Myth', Method and Theory in the Study of Religion, vol. 26, pp. 202-210.

Ricoeur, P., 1977, The rule of metaphor. The creation of meaning in language, Routledge, London.

Ricoeur, P., 1992, Oneself as another, University of Chicago Press, Chicago.

roman-empire.net, n.d. Roman Society, Roman Life, viewed 18 November 2015, from www.roman-empire.net/society/society.html\#clients

Schultz, W., 2000, Cassirer and Langer on myth: An introduction, Garland Publishing, New York.

Segal, R.A., 1998, Jung on mythology, Routledge, London. 
Segal, R.A., 1999, Theorizing about myth, University of Massachusetts Press, Amherst, MA.

Sørenson, B. \& Thellefsen, T., 2006, 'Metaphor, concept formation, and esthetic semeiosis in a Peircian perspective', Semiotica 161(1), pp. 199-212.

Stawinski, A., 2005, 'Truth in Myth and Science', Dialogue and Universalism Issue 1-2, pp. 71-78.

Stewart, D., 1971, The pyramids and the sphinx, Newsweek, New York.

Tendahl, M. \& Gibbs, R.W., 2008, 'Complementary perspectives on metaphor, Cognitive Linguistics and Relevance Theory', Journal of Pragmatics, vol. 40, pp. 1823-1864.
Tychkin, P., 2015, 'Myth as an Anthropological Phenomenon in the Context of Modern Cognitive Processes', Procedia - Social and Behavorial Sciences, vol. 166, pp. 460-463.

Van Aarde, A.G., 2003, 'Theorizing about Myth', Acta Patristica et Byzantina, vol. 14, pp. 245-265.

Van Luxemburg, J., Bal, M. \& Westeijn, W.G., 1983, Inleiding in de literatuurwetenschap, 3 rd rev. edn., Coutinho, Muiderberg.

Van Staden, P., 2005, Towards a greater God. The evolution of religion, 2nd rev. edn., Imaging Data Solutions, Cape Town. 